\title{
The Effect of FinTech on the Financial Institution in Six ASEAN Countries: Fama-French Five-Factor Asset Pricing Model Approach
}

\author{
ChiaSean Low ${ }^{1 *}$, MeiFoong Wong ${ }^{1}$
}

\author{
${ }^{I}$ Faculty of Accountancy, Finance and Business, Tunku Abdul Rahman University College, Kuala Lumpur, Malaysia \\ *Corresponding author. Email: chiasean@tarc.edu.my
}

\begin{abstract}
This study aimed to address the varying effects of FinTech growth across six ASEAN countries as the result of geographical heterogeneity of the FinTech start-ups. We examined both the supply and demand drivers to the growth of the FinTech start-ups on the stock returns of 70 incumbent banks across six ASEAN countries from 2012 to 2018. Annual data of the supply drivers such as dollar-funding volume, number of deals and number of FinTech companies were created, and the demand drivers such as internet banking population, alternative financial service providers and unbanked population, were regressed against the incumbents' stock returns with panel data analysis. The findings indicate that the relationships between the FinTech growth and incumbents' stock returns in Singapore and Philippine are positive while there is insignificant negative relationship to the incumbents in Indonesia and insignificant positive relationship to the incumbents in Vietnam. FinTech growth in Malaysia and Thailand were found to have no effect on the incumbents' stock return. These results vary across respective geographical areas in ASEAN countries due to the distinctive fundamental settings of the FinTech adoption and FinTech investment in response by the consumers and suppliers of funds contributing to the FinTech growth.
\end{abstract}

Keywords: FinTech, Traditional banks, Stock returns, ASEAN, Geographical heterogeneity, Supply drivers, Demand drivers, FinTech market growth, Consumer theory, Dynamic model of innovation

\section{INTRODUCTION}

The FinTech revolution emerged after the financial meltdown in 2008 that had ruthlessly distorted the sacred human trust in the financial ecosystem. The impact of its emergence is in fact ambiguous for the incumbent banks for their future prospect as their survival could be at stake, if the FinTech start-ups were to substitute their financial services, or they could be striving together with the FinTech start-ups to provide a customer-valued financial solution and restore the confidence and trust of the financial ecosystem.

The FinTech development in ASEAN region is witnessing the visible ascendance of catch-up games and should not be overlooked when the world has only been focusing on the tremendous FinTech growth and revolution in developed countries like in the US and China [1]. Although its development is rather embryonic with relatively lower penetration of financial products which is due to the lack of established banking habits and the geographical challenges for basic financial access [2], the financial industry may still face obstacles for the FinTech adoption.

The prospects of rapid growth in economic expansion, the rise of younger population and tech-savvy generation along with ubiquitous low-cost electronic devices have strongly supported the idea of strong digitalization potential in the ASEAN countries [2]. These fundamental settings in
ASEAN countries portrayed the upcoming radical changes to the financial industry which have been experienced in other developed countries prior to ASEAN countries. Hence, this study was to examine whether the effect of the FinTech growth in ASEAN region deviates from the developed countries which may be in contrast to the previous empirical findings from [3] which examined the FinTech start-ups on the incumbents' stock return in the US. The diverge implications of global financial crisis 2008 on ASEAN region as compared to heavily-affected western countries like US, UK, European countries and Japan [4] [5] helped to explain the distinctive FinTech development across various countries. [5] examined the contrasting expectations that are internal versus external sourced crisis, for how the regional institutions responded to the Asian Financial Crisis (AFC) 1997 and Global Financial Crisis (GFC) 2008 triggering the dispersed national institutional responses that deviated from the rest of the affected western countries. It shows the different approaches used to respond to the financial crisis comparing to Asian region and Western region which directly impacted on how the regional community perceived the needs for the financial reformation on both regions depending on the severity of the turmoil. As such, this research would study specifically on the FinTech start-ups in ASEAN countries to fill the gap of spatial segregation effect of FinTech start-ups on the incumbents in these countries. 


\subsection{Related Work}

\subsubsection{Theoretical Framework}

The entrance of FinTech activities and the sustainability of the FinTech products depends upon the two theories which intertwined the two main concerns over the FinTech disruption: Demand of the FinTech services with sufficient FinTech adoption to meet the supply of the FinTech market as well as the capability of FinTech innovation to withstand in the same market with the existing traditional banks.

\subsubsection{Consumer Theory}

It defined as "the branch of microeconomics that relates consumer demand curves to consumer preferences," [6] addresses the foundation to understand the origination of consumer demand and supply analysis. The phenomenon of FinTech development changing the traditional financial industry attributable to the customer-centric business models has the possibility of affecting the incumbent banks underlying this consumer theory [3] [7] [8] [9] [10]. This implies that these digital banking start-ups might be either positively or negatively affecting the traditional banking institutions, if they present the two alternatives of financial management to the consumers.

Moreover, the marginal-rate of substitutions of this theory also implies that a new service will be complementary if being utilised together with the old services and as opposed to that is the substitutions if the old services can be replaceable by the new services with the same needs satisfied [6] [11] [12]. The new services of these digital banking start-ups would negatively affect the traditional banking institutions for its low-cost and transparent services enabling a deeper and wider market penetration that does not require consumers to overly pay for the similar products and services they receive from the traditional banks.

\subsubsection{Dynamic Model of Innovation}

FinTech disruption in the established banking industry mimicked the prominent dynamic innovation model which is the A-U model that corroborated the dynamic process of technology evolution within an industry as well as within the member firms in the industry [13] [14] [15] [16]. The technological innovation has been evolving in the same pattern, but depending upon the complexity of the products that determine the extent to which non-technical factors will influence the technological evolution [14]. Hence, FinTech disruption may have deemed to be simpler and transparent products than the multi-layered and established financial products offered in the financial institutions and subsequently, these FinTech products are deemed to be the best technology that is likely to win the competition than the complex ones.

\subsubsection{Substitutions and Complementary between FinTech and Traditional Financial Institutions}

\subsubsection{Substitution by Disruptive Innovation}

"Disruptive innovation", that is integrated into the FinTech business models, enables the FinTech start-ups to target the overlooked market segments which are the 'underbanked' and the 'unbanked' segments such as the small businesses and rural individuals [17]. [18] supported the FinTech disruption and stated that the traditional financial institutions are often rely on the historical market position that enhances their bargaining power in the market, but the emerging FinTech start-ups rely on the underlying cuttingedge technology to provide the personalized quality services with lower cost.

[19] examined on market penetration of the largest competitive alternative lenders in FinTech industry in US LendingClub consumer-lending platform and was found to be successful in the financial provision services in the underserved areas that have few numbers of bank branches per capita and it increases their provision in areas whereas local economy is not well-performed. On the contrary, [20] stated that the countries with well-developed economy and readily-accessible venture capital will nurture the formations of FinTech start-ups. As such, based on the ideology of supply and demand drivers of FinTech growth as proposed [21], the results from both previous studies are not congruent in terms of the demand by FinTech penetration in underserved areas with not well-performing economy and the supply of FinTech services through a robust economy in aiding its formation. The number of start-ups will be higher, if the companies find it hard to access the loans [20]. Consequently, there is a mismatch of demand and supply in the FinTech industry.

[22] argued to support the potential substitutions of FinTech in the existing financial institutions by disrupting these incumbents with big data, machine learning and other technological online origination that allows the provision of financial services at the fingertips of the consumers. With the traumatized market sentiments after the GFC 2008, FinTech stands the chance of exploiting these traumatized millennials of their mistrust towards the incumbent banks whilst targeting at tech-savvy young generations altogether by offering digitalized financial services. On the other hand, incumbent banks may have the bargaining power to raise the entrance costs by means of hindering the interconnections of their established infrastructure to the FinTech companies and other types of tying strategies to aggressively halt the business survival of the new entrants [22]. As such, due to this phenomenon of intense competition, substitutions are likely to occur but who will survive in the end of the financial market would likely be a mystery.

\subsubsection{Complementary by Collaboration}

Plethora researches proved the positive conclusions of complementarity of the FinTech and incumbents [3] [21] [23] [24] [25].

[23] understated potential substitutions, but emphasized on the complementary effect of the FinTech industry for the 
overall welfare of the financial industry. [3] conducted the research on the impact of FinTech start-ups that influence the incumbents' share prices in the US and concluded the results with complementary effects between FinTech and traditional incumbents.

[21] stated that despite the mass media discussing the FinTech disruption on banks, the banks in Norway have considerable adaptability to face the new competition and instead of crumbling, they strive to improve at the same pace as FinTech firms by investing for cooperation. The authors also claimed that although FinTech possessed the disruptive effect, banks remain their positions with relevant strengths and suggested that banks that are able to adapt the new technologies into their business models and participate into cultivating new financial environment, will still survive and remain as relevant financial players.

[25] stated that FinTech could even possibly grow large enough to overtake the existing incumbents [3] and suggested the potential synergetic relationship between FinTech and the incumbents. The 'sharing economy' could be adopted whereas the consolidation of financial services and the outsourcing of FinTech assistance [25] could endup with auspicious stock reactions on the incumbents' share prices.

The business model for FinTech companies would eventually converge towards that of an incumbent bank despite that the FinTech companies may happen to provide a wide range of unbundled financial services, but in the end, these pure unbundled FinTech services may be halted due to the limited scope of financial products [24]. The only advantage of FinTech over the incumbents is the competitive technological advancement but healthy ones to enhance the efficiency of the financial market and bolster the resiliency of the incumbents to be adaptive to a new game again [24]. The incumbers may acquire the FinTech firms through merger and acquisition (M\&A), but the study conducted by [26] showed that the positive abnormal stock returns for the FinTech-acquirer firms in the short-term but over the long-run, FinTech M\&A does not create any additional value for the acquirer firms which illustrated the overreaction of the investors to the FinTech M\&A announcement in the first place, and the FinTech M\&A in developed countries has greater impact on stock returns as compared to that in the emerging countries.

\subsubsection{No Observed Effect}

As of now, there is no empirical studies proving that FinTech start-ups will not have any effect on the existing financial players unless if FinTech serves a very new market that existing incumbents do not serve. This happens due to the smaller scales of deals involved for FinTech as compared to established incumbents which deals up to trillions of dollars instead of billions, and it could also means the off-setting impact of substitutions and complementary effect between FinTech and the incumbents [3]. Another reason could be the mismatching of demand and supply of FinTech services whereas oversupplying on a stagnated demand in a particular FinTech segment and the growth rate is uncompetitive to the established financial institutions.

The demand and supply drivers of FinTech market and its vital factors to accommodate the financial services growth are displayed in Figure 1 [21]

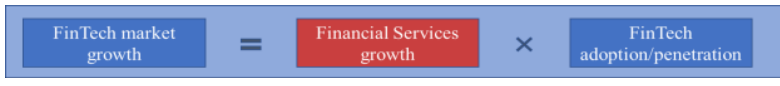

Figure 1 FinTech Driver Tree

Consumer preferences are amongst the most important demand drivers in the FinTech formation, and if FinTech start-ups are incapable of penetrating the market large enough with the sufficient disruption that forces the incumbents to react subsequently to the changes, then there would not be any impact on the incumbents and their share prices even if FinTech start-ups emerge in the financial industry [21].

\subsection{Our Contribution}

This paper contributes to the literature on FinTech start-ups emergence by distinguishing the influence of FinTech startups on traditional financial institutions in six ASEAN countries. This study presents the complementary relationship between the supply drivers of the FinTech growth by capital access with the demand drivers of FinTech adoption and the share prices of the traditional financial institutions. This study extends the cross-sectional analysis of FinTech start-ups into ASEAN countries due to the probable varying impact across different countries as compared to the developed countries conducted by [3] and [26].

\subsection{Paper Structure}

The rest of the paper is organized as follows. Section 2 develops the research hypotheses. Section 3 presents the data and model specifications. Section 4 presents the results and discussions. Finally, Section 5 provides the conclusions.

\section{HYPOTHESES DEVELOPMENT}

If the disruption of FinTech start-ups induces a significant effect on the financial industry, the estimated stock reaction will also be negatively affected [3]. The disruptive pressure of innovation will suppress the incumbents and their stock prices [27]. Prior studies showed that external capital funding provides a credible proxy to measure the future prospect of FinTech start-ups, whereas external funding serves as the critical success factor for their growth and survival [3] [28] [29] [30]. Therefore, it is reasonable to stipulate the positive relationship between the FinTech's external capital funding and the FinTech start-ups' value. The funding for FinTech digital banking start-ups will be used to measure the growth and generate the following null hypothesis: 
$H_{1}$ : There is no substitution effect of ASEAN FinTech startups on the stock returns of ASEAN incumbent banks.

The collaboration of FinTech start-ups with the established financial players is what investors look upon as a future prospect and subsequently react positively on their share prices [3]. The following null hypothesis will be aligned to the findings with the same measuring proxy:

$\mathrm{H}_{2}$ : There is no contemporaneous effect of ASEAN FinTech start-ups on the stock returns of ASEAN incumbent banks.

According to Figure 1, the underlying FinTech drivers for the technology infusion into the financial ecosystem today does not only include the supply drivers which is in this study, the external capital access to fund the FinTech startups [21]. The FinTech adoption-rate is influenced by the consumers and banks that will affect the demand for the FinTech services. Thus, this factor demonstrates as one of the crucial demand drivers of the FinTech start-ups and represents the overall FinTech industry when incorporating with the supply drivers [3] [26] for the growth of Fintech start-ups. Supply and demand for the FinTech start-ups in ASEAN will determine its growth and impact on the incumbents' share prices. To measure the impact of FinTech adoption in relation to the incumbents' share prices, the following null hypothesis was applied:

$H_{3}$ : There is no relationship between the FinTech adoption and incumbent banks' stock return.

\section{METHODOLOGY AND DATA}

\subsection{Fama-French Five-Factor Model}

[32] extended the three-factor model [31] into five-factor model inclusive of profitability and investment factors:

$$
\begin{aligned}
& E\left(R_{i}\right)-R_{f}=b_{i}\left[E\left(R_{m}\right)-R_{f}\right]+s_{i} E(S M B)+ \\
& h_{i} E(H M L)+r_{i} E(R M W)+c_{i} E(C M A)
\end{aligned}
$$

Table 1 Fama-French Five-Factor Variables

\begin{tabular}{ll}
\hline Variables & Explanation \\
\hline$R_{i}$ & The return on asset $I$ \\
$R_{f}$ & The risk-free rate \\
$R_{m}$ & The return of the value-weighted market portfolio \\
SMB & $\begin{array}{l}\text { The equal-weighted average returns of the three small-sized stock portfolios minus that } \\
\text { of the three big-sized stock portfolios }\end{array}$ \\
HML & $\begin{array}{l}\text { The average portfolio returns of the high book-to-market stocks minus that of the low } \\
\text { book-to-market stocks. }\end{array}$ \\
RMW & $\begin{array}{l}\text { The average portfolio returns of robust operating profitability minus that of the weak } \\
\text { operating profitability. }\end{array}$ \\
CMA & $\begin{array}{l}\text { The average portfolio returns on the conservative investment portfolios minus that of the } \\
\text { aggressive investment portfolios. }\end{array}$ \\
\hline
\end{tabular}

Source: [32]

\subsection{Supply Drivers of FinTech Market Growth}

This study sourced the data from the venture-finance data provider - Tracxn to identify the FinTech start-ups in
Southeast Asia that is closely related to the overall banking operations. Tracxn was chosen because of the broad coverage of start-ups data and is widely used in EY ASEAN FinTech Census 2018 report [1] amongst other Tracxn cohort publications.

To retrieve the sample, sector analysis under FinTech category amongst the other selections in the Tracxn platform tracks the investment trend of the FinTech investment growth by yearly basis from the year 2012 to 2018 as monthly data is constrained by the limited funding activity in each country on the monthly basis and aggregated annual funding activity is sampled to reduce the monthly data volatility.

The sample chose to begin in the year 2012 as data in the year 2009 for all six ASEAN countries are restricted in Tracxn. The sampling for this study ends 2 years beyond the study sample conducted by [3] to reflect the latest trend of FinTech start-ups growth in ASEAN countries.

There are six transformed variables in total used in panel regression with two variables measuring each primary proxy variable (Table 2). These three variables were transformed by applying natural logarithm to the absolute values to derive the first difference of the values [21].

\begin{tabular}{|c|c|c|}
\hline FinTech Variables & Transformed Variables & Formula \\
\hline \multirow[t]{2}{*}{ Dollar-funding Volume } & Dollar-funding volume & $\ln x_{t}, t=2,3, \ldots n$ \\
\hline & Dollar-funding volume growth rate & $\begin{array}{l}g_{t}=\ln x_{t}-\ln x_{t-1}, t= \\
2,3, \ldots n\end{array}$ \\
\hline \multirow[t]{2}{*}{ Number of Deals } & Number of deals & $\ln x_{t}, t=2,3, \ldots n$ \\
\hline & Number of deals growth rate & $\begin{array}{l}g_{t}=\ln x_{t}-\ln x_{t-1}, t= \\
2,3, \ldots n\end{array}$ \\
\hline \multirow{2}{*}{$\begin{array}{l}\text { Number of Companies } \\
\text { Created }\end{array}$} & Number of companies created & $\ln x_{t}, t=2,3, \ldots n$ \\
\hline & $\begin{array}{l}\text { Number of companies created } \\
\text { growth rate }\end{array}$ & $\begin{array}{l}g_{t}=\ln x_{t}-\ln x_{t-1}, t= \\
2,3, \ldots n\end{array}$ \\
\hline
\end{tabular}

Table 2 Data Transformation for Supply Drivers

\subsection{Demand Drivers of FinTech Market Growth}

This study used internet banking usage as a representation of population that uses the internet banking in a country. It is reasonable to assume the positive relationship between internet penetration and internet banking usage as a proxy of tech-savvy level of the population.

The second variable is the alternative financial service providers which is the provision of financial services by non-bank organisations. The basic assumption is that if the alternative financial service providers are not able to sustain their businesses alongside with the main financial service providers, it can be described as the lack of demand for the alternative financial services whilst heavily relied on the mainstream financial institutions. Therefore, if there is a demand for FinTech services which are also the contributors of the provision of alternative financial service [2], there is a potential growth for FinTech industry in providing alternative financial services to the community. The last variable is the demographic indicator, namely the unbanked population, to gauge the intensity of financial inclusion that is the access and the use of financial services of the FinTech industry on a country in order to alleviate individuals' financial prosperity and reduce poverty [33] [34]. 
Table 3 Data Transformation for Demand Drivers

\begin{tabular}{llll}
\hline FinTech Variables & & Transformed Variables & Formula \\
\hline Internet Banking & $(\%$ of & Growth Rate of the Usage of & $g_{t}=\ln x_{t}-\ln x_{t-1}, t=$ \\
population) & & Internet Banking & $2,3, \ldots n$ \\
Alternative & Financial & Growth Rate of the Alternative & $g_{t}=\ln x_{t}-\ln x_{t-1}, t=$ \\
Service Providers (USD & Financial Service Providers & $2,3, \ldots n$ \\
million) & & \\
Unbanked Population (\% of & Growth Rate of the Unbanked & $g_{t}=\ln x_{t}-\ln x_{t-1}, t=$ \\
population) & Population & $2,3, \ldots n$ \\
\hline
\end{tabular}

These variables were sourced from Euromonitor on annual basis (Table 3). These variables were being transformed by natural logarithm differences to obtain the growth-rates for each variable that are representable to the magnitude of FinTech adoption in a country rather than standardizing its absolute values.

\subsection{Fama-French Five-Factor Asset Pricing Factors}

Secondary annual data was gathered from Thomson Reuters DataStream from the year 2012 to 2018 to be aligned with the data availability of supply and demand drivers to the FinTech companies and adoption (Table 4). A total of 70 banks and 2,195 companies for all six countries disregard of industries were used for the construction of portfolios.

Table 4 Data Collection for Fama-French Variables

\begin{tabular}{|c|c|}
\hline \multicolumn{2}{|c|}{ Panel A: Data Collection for Fama and French Variable Groups } \\
\hline Excess Banks' Stock Return & Total Return Index of Banks \\
\hline Excess Market Return & Price Index of Stock Exchanges \\
\hline Size & Market Capitalisation of Individual Stock \\
\hline Value & Market to Book Value of Individual Stock \\
\hline Profitability & Operating Income of individual Stock \\
\hline Investment & Total Assets of Individual Stock \\
\hline \multicolumn{2}{|c|}{ Panel B: Data Collection for Risk-free Rates by Countries } \\
\hline Country & \\
\hline Indonesia & 1-Year Indonesia Interbank Rate \\
\hline Malaysia & Malaysia T-Bill Band 10 \\
\hline Philippine & Philippine Treasury Bill 364 Days \\
\hline Singapore & 1-Year Singapore Interbank Rate SIBOR \\
\hline Thailand & 1-Year Thailand Interbank Rate \\
\hline Vietnam & 1-Year Vietnam Interbank Rate \\
\hline
\end{tabular}

\subsection{Model Specification}

The Fama and French Five-factor model has been extended to accommodate the FinTech variables as follow:

$R_{i t}-R_{f t}=\alpha_{i}+\beta_{1} R M R F_{t}+s_{i} S M B_{t}+h_{i} H M L_{t}+$

$r_{i} R M W_{t}+c_{i}$ CMA $_{t} \quad+\gamma F U N D F T_{t}+\varepsilon_{i, t}$

whereas:

$F U N D F T=$ Dollar-funding volume with its growth-rate, number of deals with its growth-rate and number of FinTech companies created with its growth-rate.

$R_{i t}-R_{f t}=\alpha_{i}+\beta_{1} R M R F_{t}+s_{i} S M B_{t}+h_{i} H M L_{t}+$

$r_{i} R M W_{t}+c_{i} C M A_{t}+\gamma A D O P T F T_{t}+\varepsilon_{i, t}$ whereas:

$A D O P T F T=$ Internet-banking growth-rate, alternative financial service providers growth-rate and unbanked population growth-rate.

Each of the two models were repeatedly regressed by each FinTech variables of the total six variables for supply drivers and three variables for demand drivers and by each country of six countries. There were 36 model estimations catered to each six FinTech supply drivers and another 18 model estimations catered for each three FinTech demand drivers.

Panel data analysis was applied. The sample data, which is said to be balanced for all the variables, were filtered to remove any missing values in the sorting process of Fama French Five-factor construction from the year 2012 to 2018. Regression analysis with three model estimations on the model specifications mentioned in the previous section were examined namely Pooled Ordinary Least Squares (OLS) model, Fixed Effect (FE) model and Random Effect (RE) model. The results of Breusch and Pagan LM test for random effects model showed that Pooled OLS model was used for this study as shown in Table 5. Except the OLS models of Singapore and Vietnam, the remaining countries were being tested by robust standard error estimation as shown in Table 6 to rectify the models with heteroskedasticity problems for Indonesia, Malaysia and Thailand, but clustering was applied to the model of Philippine for the heteroskedasticity problem and serial correlation.

Table 5 Pooled OLS Model Results

\begin{tabular}{|c|c|c|c|c|c|c|c|}
\hline Variables & & Fundng Volume & Grouth Volume & Nunber of Deals & Growt Deals & FinTech Comparies created & GrouthFhTech Conparies \\
\hline \multirow[t]{3}{*}{ Indonesia } & Coefficient & -0.0499 & -0.1145 & 0.1799 & -21.2883 & -6.1113 & 0.3768 \\
\hline & Std Eror & 18326 & 4.2071 & 6.6073 & 15.6787 & 24,4685 & 138386 \\
\hline & R.Squared & 0.0604 & 0.0604 & 0.0604 & 0.0603 & 0.0604 & 0.0604 \\
\hline \multirow[t]{3}{*}{ Malaysia } & Coefficient & 4.7182 & -0.6467 & .58983 & -4.1793 & 10.2843 & 2.3912 \\
\hline & Std Eror & 20.7523 & 2.8446 & 259426 & 18.3819 & 45.2340 & 10.5171 \\
\hline & R-Squared & 0.4261 & 0.4261 & 0.4261 & 0.4261 & 0.4261 & 0.4261 \\
\hline \multirow{3}{*}{ Ptilippire } & Coefficient & 14.5102 & 21.0799 & 48.0330 & 5.1261 & 3.3479 & 242680 \\
\hline & Std Eror & 88101 & 18.8823 & 43.034 & 25.4028 & 149570 & 12.1482 \\
\hline & R-Squared & 0.1175 & 0.1188 & 0.1188 & 0.1025 & 0.1026 & 0.0629 \\
\hline \multirow[t]{3}{*}{ Sineppore } & Coefficient & $6.097371^{\text {s }}$ & $107.3589 * 8$ & $21.79917^{78}$ & $3295109^{*}$ & $41.39351^{* *}$ & $19.81016^{* *}$ \\
\hline & Std Eror & 25888 & 4.9204 & 8.6166 & 15.8870 & 17.3196 & 7.6393 \\
\hline & R-Squared & 0.8478 & 0.8568 & 0.8538 & 0.8349 & 0.8668 & 0.8533 \\
\hline \multirow{3}{*}{ Thiil and } & Coefficient & .21897 & -3.1518 & -61.13909* & 14.9751 & .11 .4131 & 5.9188 \\
\hline & Std Eror & 23208 & 6.9415 & 33.0895 & 9.2967 & 7.6521 & 8.0687 \\
\hline & R-Squared & 0.2264 & 0.2172 & 0.2567 & 0.2462 & 0.230 & 0.212 \\
\hline \multirow{3}{*}{ Viettrmm } & Coefficient & 27397 & 4.7722 & 13.5018 & 31.5330 & 11.3656 & .24 .7871 \\
\hline & Std Error & 3.9045 & 6.8012 & 19.2424 & 44.9401 & 16.1979 & 353259 \\
\hline & $\begin{array}{l}\text { R-Squared } \\
\text { Res }\end{array}$ & 0.3903 & 0.3903 & $\begin{array}{l}1.34249 \\
0.3903\end{array}$ & 0.3903 & 0.3903 & 0.3903 \\
\hline
\end{tabular}

Table 5 Pooled OLS Model Results (Continued)

\begin{tabular}{|c|c|c|c|c|}
\hline Variables & & Internet Banking & Altemative Financial Service Provider & Unbanked Populatior \\
\hline \multirow[t]{3}{*}{ Indonesia } & Coefficient & 3.4128 & -48.7939 & -42.4153 \\
\hline & Std. Error & 125.3521 & 1792.1950 & 1557.9080 \\
\hline & R-Squared & 0.0604 & 0.0604 & 0.0604 \\
\hline \multirow[t]{3}{*}{ Malaysia } & Coefficient & 60.8242 & 52.7349 & 137.5066 \\
\hline & Std. Error & 267.5255 & 231.9460 & 604.8012 \\
\hline & R-Squared & 0.4261 & 0.4261 & 0.4261 \\
\hline \multirow[t]{3}{*}{ Philippine } & Coefficient & 606.9426 & 1643.7730 & 17399.0900 \\
\hline & Std. Error & 546.8879 & 9430.5980 & 15585.2200 \\
\hline & R-Squared & 0.1023 & 0.1057 & 0.1188 \\
\hline \multirow[t]{3}{*}{ Singapore } & Coefficient & $191.5166^{* *}$ & -63.2322 & $126.0365^{* *}$ \\
\hline & Std. Error & 80.2157 & 47.6400 & 51.0667 \\
\hline & R-Squared & 0.8460 & 0.8824 & 0.8489 \\
\hline \multirow[t]{3}{*}{ Thailand } & Coefficient & $760.4658^{*}$ & -147.4192 & 2093.93* \\
\hline & Std. Error & 411.5765 & 90.8636 & 1133.2690 \\
\hline & R-Squared & 0.2567 & 0.2466 & 0.2567 \\
\hline \multirow{3}{*}{ Vietram } & Coefficient & 381.1868 & 3504.7150 & -205.2476 \\
\hline & Std. Error & 543.2576 & 4994.8290 & 292.5135 \\
\hline & R-Squared & 0.3903 & 0.3903 & 0.3903 \\
\hline
\end{tabular}


Table 6 Robust Standard Error and Cluster Model Estimation Results

\begin{tabular}{|c|c|c|c|c|c|c|}
\hline $\begin{array}{l}\text { Variables } \\
\end{array}$ & Funding Volume & Growth Volume & Number of Deals & Grouth Deals & FinTech Comparies created & Growth FlTTech Companies \\
\hline Indonesia Coefficient & .0 .0499 & -0.1145 & -0.1799 & .21 .2883 & -6.1113 & 0.3768 \\
\hline Std. Error & 2.1561 & 4.9497 & 7.7735 & 19.2999 & 264.0893 & 16.2813 \\
\hline R-Squared & 0.0604 & 0.0604 & 0.0604 & 0.0603 & 0.0604 & 0.0604 \\
\hline Malaysia Coefficient & 4.7182 & -0.6467 & .5.8983 & -4.1793 & 10.2843 & 2.3912 \\
\hline Std Error & 14.3328 & 1.9647 & 17.9176 & 12.6957 & 31.2415 & 7.2638 \\
\hline R-Squared & 0.4261 & 0.4261 & 0.4261 & 0.4261 & 0.4261 & 0.4261 \\
\hline Philippine Coefficient & $14.5102^{* *}$ & $21.07989 * x *$ & $48.05302^{2 * * *}$ & 5.1261 & 3.3479 & $24.2680^{*}$ \\
\hline Std Error & 7.0368 & 8.1169 & 18.5030 & 20.5125 & 12.2076 & 14.5624 \\
\hline R-Squared & 0.1175 & 0.1188 & 0.1188 & 0.1025 & 0.1026 & 0.0629 \\
\hline Thailand Coefficient & .2 .1897 & .3 .1518 & $-61.13909^{*}$ & 14.9751 & $-11.4131^{*}$ & 5.9188 \\
\hline Std. Error & 2.4057 & 8.4518 & 16.1250 & 6.6587 & 6.3383 & 9.8778 \\
\hline R-Squared & 0.2264 & 0.2172 & 0.2567 & 0.2462 & 0.2230 & 0.2212 \\
\hline
\end{tabular}

Table 6 Robust Standard Error and Cluster Model Estimation (Continued)

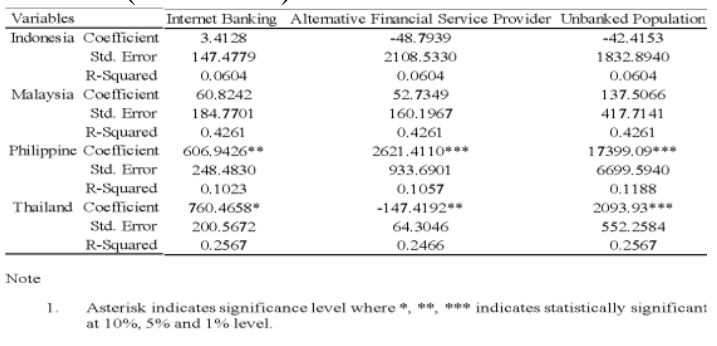

\section{RESULTS AND DISCUSSIONS}

Table 7 reports that Singapore and Philippine rejected the null hypothesis with a statistically positive significance when examining the supply drivers and demand drivers of the FinTech activities which proves the complementary effect between the ASEAN FinTech start-ups and the incumbent banks' stock return, and a positive relationship between the FinTech adoption and the incumbent banks' stock return.

Indonesia, Malaysia, Thailand and Vietnam are shown to have no clear effect on either substitution or complementary effect and failed to reject the null hypothesis with the statistically insignificant empirical results and insignificant mixed relationships between the FinTech adoption and the incumbent banks' stock return.

Table 7 The Summarized Effect of FinTech Growth on Traditional Financial Institution for Six ASEAN Countries

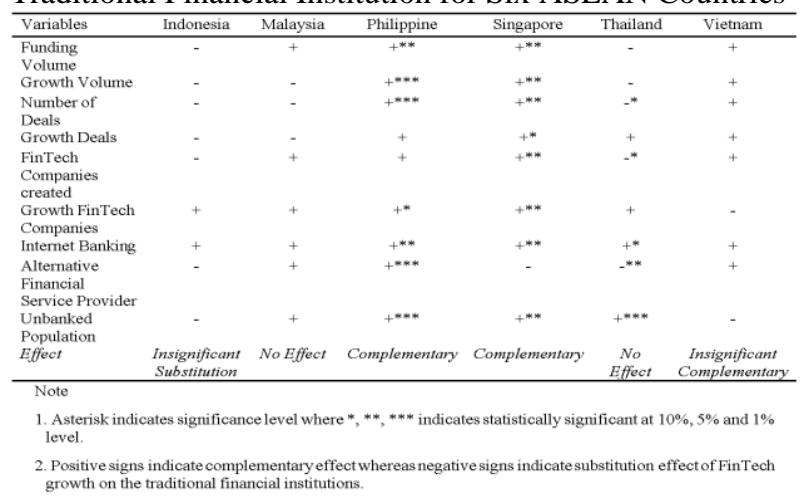

The complementary effect of FinTech start-ups and incumbent banks in Singapore and Philippine is supported by [3]. Thus, there is no indication of creative destruction by the FinTech industry [3] [24]. Instead, the growth of Fintech industry in Singapore and Philippine has positive spill-over effects to the traditional financial industry [3] and to their stock returns after the FinTech received funding for the development [26]. Nonetheless, the contributing factors behind the complementary of Singapore and Philippine may be varied from each other.

Despite having the lowest number of populations among the six countries, Singapore excelled in the FinTech development wherein the demand and the supply of Fintech activities are interacted due to the strategic demographic, technological, and economics landscape in Singapore [36]. Hence, this explains the positive relationship between the internet banking growth and the incumbent banks' stock price, and the result shows that shall there be any unbanked population in Singapore, the incumbent banks are likely to serve the market by collaborating with the FinTech start-ups to serve this underserved population. Thus, the barrier of entry for the FinTech start-ups has been reduced which consequently allows the technological innovation operates smoothly throughout the phases in A-U model.

The FinTech start-ups in Philippine, on the other hand, revealed to have various reasons for its complementary with the incumbent banks. The higher the difficulty to access for financial services such as loans, the higher will be the number of FinTech start-ups created [21]. As such, exploiting on the underserved market whereas most of the population are unbanked, the FinTech start-ups in Philippine can provide financial services to alleviate their poverty, financial literacy, and financial stability. The supply drivers of FinTech activities from the empirical results are shown to be positively significant to the incumbent banks' stock return. This means that the FinTech industry is growing in a conducive environment and that the incumbent banks need FinTech start-ups just as much as the FinTech start-ups need the incumbent banks. The FinTech development in Philippine would have smoother transition stages from the entry to the potential convergence of the business models between the FinTech start-ups and the incumbent banks.

The empirical results conclude with insignificant substitution effect for Indonesia and insignificant complementary effect for Vietnam whereas there is no observed effects for the Malaysia and Thailand. FinTech industry in these countries do not have any spill-over effect on the traditional financial institutions.

No observed effects are resulted from the offsetting effects of substitutions and complementary between the Fintech development in six ASEAN countries and the incumbent banks due to any of the probable events in Table 8 [3]:

Table 8 Probably Events of No Observed Effects

\begin{tabular}{lll}
\hline Probable Events & Explanations & Countries \\
\hline (1) & FinTech start-ups serve new market that incumbents do not serve. \\
(2) & $\begin{array}{l}\text { Large FinTech acquisition initiatives by incumbents leads to } \\
\text { inconclusive relationship for the funding on FinTech and their }\end{array}$ & Vietnam \& Malaysia \\
stock returns. & $\begin{array}{l}\text { Small-sized FinTech as compared to established incumbents } \\
\text { where the scales of deals involved are relatively larger in } \\
\text { denomination for incumbents. }\end{array}$ & Indonesia \\
(3) & $\begin{array}{l}\text { Ingrained strengths of incumbents with customer's trust long } \\
\text { before the birth of FinTech }\end{array}$ & Indonesia \\
(5) & $\begin{array}{l}\text { Mismatching demand and supply for FinTech growth seems } \\
\text { unattractive to the established incumbents. }\end{array}$ & Vietnam \& Thailand \\
\hline
\end{tabular}


Indonesia has the highest number of incumbents in this study and the possible reason for the insignificant effect is due to (3) the incumbents' established market shares in the financial market which would impose high cost of entry for the FinTech start-ups [2]. Also, (4) the consumers do not seem to see the needs to change their financial providers and thus, relying heavily on the incumbent banks for financial products. Despite having the highest population, Indonesia has the lowest digital readiness with slow FinTech adoption due to the lack of knowledge on the consumers' behaviour [2]. The technological innovation changes in Indonesia is still on its fluid phase according to the A-U model. Hence, the market is ambiguous on the viability of FinTech products and that the initial response to such entrance for the incumbent banks may have been hostile towards such radical shift or still configure on how to respond to the FinTech activities, whether they should adapt or compete. Vietnam has limited and rather inactive FinTech activity stemming from the lack of demand for FinTech services [1]. The active but inconclusive collaboration of the incumbent banks with FinTech start-ups over the short-term (2), and (5) the oversupply of FinTech services in the market results in insignificant complementary effect.

The incumbents in Malaysia have shown their initiations of adapting FinTech (2) by re-engineering their business models [2]. Such business strategies are complementary to their stock returns but nonetheless, reducing the competition in the market by acquisition may not be the ultimate long-term solution for the incumbents while the regulators on the other side of the game are enabling a common and viable playing field for the FinTech start-ups to strive together with the existing incumbents.

The effects of FinTech on incumbents in Thailand (5) were found to be the competition not only from the incumbent banks, but also from the non-banks [2]. The statistically moderate substitutions effect coupled with the statistically strong demand for FinTech services on the general view on the empirical results, suggest that the substitution effects have offset the potential complementary effect, and as a result, no significant effect is observed.

\section{CONCLUSION}

This study aimed to examine the complementarity of the emergence of FinTech industry and the incumbent banks and inclines to investigate the effect of FinTech start-ups on the incumbent banks' stock return in six ASEAN countries. The research findings varied across distinctive geographical areas in ASEAN countries. Singapore and Philippine were found to be having significant complementary effect with the incumbent banks whereas the FinTech start-ups in Indonesia and Vietnam indicated contradicting effects on the incumbent banks which are the insignificant substitution effect and insignificant complementary effect respectively. Finally, the FinTech start-ups in Malaysia and Thailand were both observed to have no effect on the incumbent banks.

This paper intended to contribute the empirical findings to the existing literature and future research directions to address the issues of geographical heterogeneity in technological innovation in the financial industry across six ASEAN countries. These results may be useful to policymakers to formulate appropriate regulatory control in order to provide a conducive environment for the development of FinTech start-ups in the country. There are regulatory sandboxes available for certain countries, which are Indonesia, Singapore, Malaysia, and Thailand as a testdrive for the FinTech start-ups in the existing financial ecosystem. However, there are other countries such as Philippine and Vietnam that are on its way of striving towards the FinTech ecosystem, and let alone Brunei and Laos that have yet to officially jump into the bandwagon of the FinTech revolution. It is imperative for the policymakers to consider the pros and cons of these new digital financial services to the consumers and the financial landscapes. Additionally, these findings may serve as an important insight to the opportunity and challenges in investing in FinTech start-ups for investors as well as FinTech firms. Thus, this study clarified the blurring boundaries of the FinTech start-ups in the six ASEAN countries to enable customer-centric interfaces business models.

\section{REFERENCES}

\section{[1] EY. 2018, ASEAN FinTech Census 2018. EY.}

[2] Gupta, A. \& Xia, C. 2018, “A Paradigm Shift in Banking: Unfolding Asia's FinTech Adventures", Banking and Finance Issues in Emerging Markets, pp. 215-254, Emerald Publishing Limited.

[3] Li, Y., Spigt, R. \& Swinkels, L. 2017, "The impact of FinTech start-ups on incumbent retail banks' share prices", Financial Innovation, vol. 3, no. 1, pp. 1-16.

[4] Khoon, G. S. \& Lim (Mah-Hui.). 2010, 'The impact of the global financial crisis: the case of Malaysia', Third World network (TWN).

[5] Emmers, R. \& Ravenhill, J. 2011, “The Asian and global financial crises: consequences for East Asian regionalism". Contemporary Politics, vol. 17, no. 2, pp.133-149.

[6] Piros, C.D., Pinto, J.E. \& Harris, L. 2013, Economics for investment decision makers: micro, macro, and international economics, Wiley, Hoboken, NJ.

[7] Lin, Z., Whinston, A.B. \& Fan, S. 2015, "Harnessing Internet finance with innovative cyber credit management", Financial Innovation, vol. 1, no. 1. 
[8] Wang, H., Chen, K., Zhu, W. \& Song, Z. 2015, “A process model on P2P lending”, Financial Innovation, vol. 1 , no. 1 .

[9] Wang, P., Zheng, H., Chen, D. \& Ding, L. 2015, "Exploring the critical factors influencing online lending intentions", Financial Innovation, vol. 1, no. 1.

[10] Yan, J., Yu, W. \& Zhao, J.L. 2015, “How signaling and search costs affect information asymmetry in P2P lending: the economics of big data", Financial Innovation, vol. 1 , no. 1 .

[11] Aaker, D.A. \& Keller, K.L. 1990, “Consumer Evaluations of Brand Extensions”, Journal of Marketing, vol. 54, no. 1, pp. 27-41.

[12] Frank, R. 2009, Microeconomics and Behavior, McGraw-Hill Education, Boston.

[13] Afuah, A.N. \& Utterback, J.M. 1997, "Responding to structural industry changes: a technological evolution perspective", Industrial and corporate change, vol 6(1), pp.183-202.

[14] Tushman, M. L. 1992, “Organizational determinants of technological change: toward a sociology of technological evolution", Research in organizational behaviour, vol. 14, pp. 311-347.

[15] Bessant, J., Lamming, R., Noke, H. \& Phillips, W. 2005, "Managing innovation beyond the steady state", Technovation, vol. 25 , no. 12, pp. 1366-1376.

[16] Beausoleil, A. M. 2019, "Revisiting Rogers: the diffusion of his innovation development process as a normative framework for innovation managers, students and scholars", Journal of Innovation Management, vol. 6, no. 4, pp.73-97.

[17] Christensen, C.M., Raynor, M.E. and McDonald, R., 2015. What is disruptive innovation. Harvard business review, 93(12), pp.44-53.

[18] Kauffman, R., Liu, J. \& Ma, D. 2015, "Competition, cooperation, and regulation: Understanding the evolution of the mobile payments technology ecosystem", Electronic Commerce Research and Applications, vol. 14, no. 5, pp. 372-391.

[19] Jagtiani, J. \& Lemieux, C. 2018, "Do fintech lenders penetrate areas that are underserved by traditional banks?", Journal of Economics and Business, vol. 100, pp. 43-54.

[20] Haddad, C. \& Hornuf, L. 2019, "The emergence of the global fintech market: economic and technological determinants", Small Business Economics, vol. 53, no. 1, pp. 81-105.

[21] Omreng, S. \& Gjendem, I. 2017, 'FinTech in Norway: The Effect of FinTech on the Traditional Norwegian Banking Sector', Unpublished Master Thesis, Norwegian School of Economics.

[22] Vives, X. 2017, "The Impact of Fintech on Banking”, European Economy, no. 2, pp. 97-105.

[23] Jun, J. and Yeo, E., 2016, "Entry of FinTech firms and competition in the retail payments market", AsiaPacific Journal of Financial Studies, vol. 45, no. 2, pp.159-184.

[24] Navaretti, G., \& Pozzolo, A. 2017, "FinTech and Banks: Friends or Foes", European Economy, vol. 2, pp. 9-30.

[25] Arjunwadkar, P. Y. 2018, FinTech: The Technology Driving Disruption in the Financial Services Industry, CRC Press, Boca Raton, FL.

[26] Dranev, Y., Frolova, K. \& Ochirova, E. 2019, "The impact of fintech M\&A on stock returns", Research in International Business and Finance, vol. 48, pp. 353364.

[27] Sood, A. \& Tellis, G.J. 2009, "Do Innovations Really Pay Off? Total Stock Market Returns to Innovation", Marketing Science, vol. 28, no. 3, pp. 442456.

[28] Dean, B. V., \& Giglierano, J. J. 1990, “Multistage financing of technical start-up companies in Silicon Valley", Journal of Business Venturing, vol. 5, no. 6, pp.375-389.

[29] Davila, A., Foster, G. \& Gupta, M. 2003, "Venture capital financing and the growth of startup firms", Journal of Business Venturing, vol. 18, no. 6 , pp. 689-708.

[30] Mina, A., Lahr, H. \& Hughes, A. 2013, "The demand and supply of external finance for innovative firms", Industrial and Corporate Change, vol. 22, no. 4, pp. 869-901.

[31] Fama, E. F. \& K. R. French 1993, “Common risk factors in the returns on stocks and bonds", Journal of Financial Economics, vol. 33, no. 1, pp. 3-56.

[32] Fama, E. F., \& French, K. R. 2015, “A five-factor asset pricing model", Journal of Financial Economics, vol. 116, no. 1, pp.1-22. 
[33] Soriano, M. A. 2017, Factors driving financial inclusion and financial performance in Fintech new ventures: An empirical study. Unpublished PhD

Dissertations. Singapore Management University.

[34] Grohmann, A., Klühs, T. and Menkhoff, L. 2018,

"Does financial literacy improve financial inclusion?

Cross country evidence", World Development, vol 111, pp.84-96.

[35] Gnirck, M. and Visser, G. 2016, Singapore, the FinTech Hub for Southeast Asia. The FinTech Book: The financial technology handbook for investors, entrepreneurs and visionaries, United Kingdom, John Wiley \& Sons Ltd., pp.58-60. 